\title{
A Survey on Knowledge of Registered Drugs amongst Patients from the Specialist Clinic, Malaysia
}

\author{
Nur Wahida Zulkifli ${ }^{1,2}$, Mohd Amir Mohd Yunus ${ }^{1}$, Mohd Fakarul Radzi Mohamed Mustafa ${ }^{1}$, \\ Kong Wei En ${ }^{1}$, Lim Chong Yee ${ }^{1}$, Ng Weng Hong ${ }^{1}$, Nethiya Rubinee Povanesvaran ${ }^{1}$ \\ and Zalinur Zainal ${ }^{1}$ \\ ${ }^{1}$ Pharmacy Department, Hospital Selayang, Ministry of Health, Malaysia. \\ ${ }^{2}$ Centre for Healthcare Quality Research Institute for Health Systems Research, Ministry of Health Malaysia
}

\begin{abstract}
Introduction: One of the solutions to reduce unregistered drugs usage is via awareness and educational programmes. The aim of this study is to determine the significance difference of patients' level of knowledge between control and intervention groups towards registered drugs.

Method: The study used a pre- and post-test by answering the validated survey during OctoberNovember 2018 at a tertiary hospital in Malaysia. It has two groups as an intervention group (IG) receiving counseling and control group $(\mathrm{CG})$ which did not receive any counseling. This study used systematic random sampling. The data analysis was performed using SPSS version 23. Descriptive data was reported, including the answers each question, score, level of knowledge based on the percentages and the socio-demographic data. The pre and post differences of the score between control and intervention groups were assessed using ANCOVA.

Result: A total of 657 respondents were obtained which overall response rate of $93 \%$ ). Majority of the participants are aged between 18-28 years old (47\%), female (58.3), Malay (47.4\%), Degree holder $(69.1 \%)$ and in the government sector (38.3\%). However, the majority of participants are in the category of the acceptable level of knowledge towards registered drugs (40.8\%) and only 3.5\% of the participants are in the category of excellent. However, about $66.1 \%$ of the participants have scored above $50 \%$. It can be considered that the majority of the participants have knowledge about registered drugs. IG group displayed significantly higher post-test results compared with CG group $(\mathrm{p}<0.001)$.

Conclusion: The used of the validated survey during the awareness programmes might give benefit to the public who attends the awareness and educational programmes and finally can improve the effectiveness of the programmes in the future. In the future, the improvement of the design of the campaign might include the use of a survey in order to give more understanding to the public towards registered drugs. [DOI: 10.22401/ANJS.22.3.04]
\end{abstract}

Keywords: registered drugs, knowledge survey, educational campaign, counterfeit drugs.

\section{Introduction/Background}

There are many solutions to reduce unregistered drugs usage. One of the solutions is the awareness and educational program [1]. Food Drug Administration (FDA) is one of the organizations which provides information on educating the public on counterfeit drugs via a website [2]. Meanwhile, in Malaysia, Pharmaceutical Services Division (PSD) is one of the agencies that provide awareness programs throughout the country as well as in its website. One of the campaigns was "Know Your Medicines". This campaign was held to ensure that, the public is aware and responsible for types of medications they consumed and purchased [3]. It visualised that the government has placed its effort to educate and provide vital information to the public regarding health and drug-related issues. Despite the awareness program, there is still a lack of specific research to ascertain the level of public understanding regarding general knowledge towards registered drugs.

As mentioned earlier, $\mathrm{MOH}$ already has the campaign known as 'Know Your Medicine'. 'Know Your Medicine' is a programme introduced as part of Quality Use Medicines activities which, aim to ensure that patients or consumers take their medications rationally. The programmes promoted on the 5R (Right) concept, which is: patient; medicines; dose; the route of administration 
and the time of administration. There is another campaign which is the subset of the 'Know Your Medicine' programme which is known as 'Choose Registered Drugs'.

Choose Registered Drugs campaign is mainly conducted by the Enforcement Pharmacy Unit. The campaign is primarily about registered and unregistered drugs information. All of the information in the campaign is more focused about the characteristic of registered drugs, cosmetic, advertisement, online shopping, the harmful effect of unregistered drugs and the danger of food and drink that contaminated with poison [4].

The information of unregistered drugs characteristic is valuable information that every consumer in Malaysia need to know before they buy any pharmaceutical products whether in the market or online. The registered drugs aspect is every pharmaceutical product must have MAL number as registration and Hologram label on the packaging. Consumers need to be aware of the pharmaceutical products that they bought. They need to check the registration number via the website and to confirm that the label is authentic. The consumers also need to go to any registered pharmacy store to use the hologram Meditag ${ }^{\circledR}$ to identify the originality of the sticker. It is the fundamental requirement that every consumer need to be aware and understands [4].

There are several types of research in 'Konvensyen Inovasi Kebangsaan Farmasi' (KIKF), and Quality Assurance (QA) which investigated this matter. One study in KIKF, which was conducted by Enforcement Pharmacy Kelantan, assessed the understanding of registered drugs amongst healthcare provider in Kelantan throughout 2013. The findings found that only $19.5 \%$ of the respondents understand the registered drugs. Rasyimah et al., 2013, claimed that after the counselling session to all of the participants, the assessment of understanding result increased to $80.1 \%$ [5].

There is a National Survey on the Use of Medicines (NSUM) by Malaysian Consumers conducted by PSD to evaluate the performance of the "Know Your Medicines" campaign in 2012. The primary purpose of this study was to help to establish the QUM nationwide and directly embark the initiatives done in the 10th Malaysia Health Plan [6]. NSUM is the pioneer in the field of study that used as a foundation for this study. According to the result from NSUM, up to $76.4 \%$ of the participants were aware of the requirement to register with $\mathrm{MOH}$ for all modern and traditional medicines before marketing them [6]. Furthermore, only $38.7 \%$ of the participants were aware of Meditag® availability [6]. These results showed that the majority of Malaysian consumers did not know about Meditag ${ }^{\circledR}$ and its functions. The result of the awareness is high, which showed that participants were aware of the requirement for registration but at the same time, they did not know what Meditag ${ }^{\circledR}$ is. Knowledge about Meditag $®$ is one of the crucial pieces of information that consumers need to know to prevent them from buying unregistered drugs.

Furthermore, the statistics of unregistered drug confiscated is increasing in trend since 2010 and the value has amounted to RM 27 million per year [7]. Surprisingly, the possibility that the statistics might increase every year might be possible [8]. There are also reports on the increasing trend of adverse drug reaction had been indicated that experienced by consumers after they consumed the unregistered drugs [9]. This report gives a reflection that there are still demands from the consumers towards unregistered drugs. Both of these issues showed that consumers need to be more knowledgable and alert about these issues. It is to prevent any harm to them whether in short term or long term of adverse drug reactions.

\section{Rationale of the study}

The used of a validated tool to assess public knowledge on the registered drugs might help the public and pharmacists to identify the knowledge that the public is lacking and straight away give education on the topic that they less understand. Moreover, in this study, it would be beneficial to assess the efficacy of the current awareness and educational programmes in order to fill in the gaps of the previous study. 


\section{1- Justification of the study}

The Ministry of Health (MOH) administrates the Malaysian National Medicines Policy (MNMP) that acts to promote equitable access and rational use of safe, effective, and affordable essential medicines of good quality to improve health outcomes. In the policy have five strategies have been reorganized. One of these strategies addresses counterfeit drugs Table (1).

The main concern is to ensure all products in the market (online and shops) are registered [10]. Many solutions may be considered. One such solution is to educate and give awareness to the public concerning registered drugs [11]. According to the policy, public awareness and roadshow on counterfeit issues is one of the activities that need to be implemented. Therefore, the aim of this study is to add-on the use of the validated survey during the campaign might possibly increase the benefits to the public that attend the campaign.

\section{2- The Validated Survey}

The survey is already validated and conducted in the Malaysia setting [12]. The final version of the questionnaire had 12 questions which are divided into five areas of information that needed for educating the consumer on registered drugs. This questionnaire had a clarity index of $8.78 \pm$ 0.51 . The intraclass correlation coefficient was 0.96, and Cronbach's alpha, 0.866. The information in the survey is the combination some of the result from the qualitative study and the extraction of the information from the 'Choose Registered Drugs' campaign. The survey is multiple choices and if they do not know the answer they can answer E (I do not know).

\section{Quality, Safety and Efficacy of Medicines Strategy: Counterfeit Drugs.}

\begin{tabular}{|c||c||c||c||c||c||}
\hline No & Activities & $\begin{array}{c}\text { Implementation } \\
\text { Timeline }\end{array}$ & Indicators & Targets & Stakeholder \\
\hline \hline 1 & $\begin{array}{c}\text { Monitoring of retailers } \\
\text { and wholesaler through } \\
\text { inspection }\end{array}$ & $\begin{array}{c}\text { 2016-2017 (upon the } \\
\text { effective date of } \\
\text { New Pharmacy Act) }\end{array}$ & $\begin{array}{c}\text { Percentage of } \\
\text { counterfeit drugs } \\
\text { confiscated }\end{array}$ & $\begin{array}{c}\text { TBD (to get } \\
\text { baseline data) }\end{array}$ & $\begin{array}{c}\text { Local } \\
\text { Authorities } \\
\text { PSD }\end{array}$ \\
\hline \hline 2 & $\begin{array}{c}\text { Public Awareness and } \\
\text { roadshow on counterfeit/ } \\
\text { SSFFC issues }\end{array}$ & On-going & $\begin{array}{c}\text { Number of } \\
\text { activities conducted }\end{array}$ & $\begin{array}{c}\text { Not less than } \\
50 \text { per year }\end{array}$ & PSD \\
\hline \hline 3 & $\begin{array}{c}\text { Comprehensive } \\
\text { monitoring of the illegal } \\
\text { online sale of medicine } \\
\text { by Pharmacy Digital } \\
\text { Forensic Unit }\end{array}$ & $\begin{array}{c}\text { Percentage of } \\
\text { websites selling } \\
\text { medicine illegally } \\
\text { for which action is } \\
\text { taken }\end{array}$ & $\begin{array}{c}\text { Not less than } \\
50 \% \text { TBD }\end{array}$ & PSD, \\
\hline
\end{tabular}

Source: Malaysian National Medicines Policy (MNMP) 2014

*Pharmaceutical Services Division (PSD), Malaysian Communications and Multimedia Commission (MCMC)

\section{METHODOLOGY}

This prospective cohort study used a preand post-test by answering the validated survey Fig.(1). It has two groups as an intervention group (IG) receiving counseling and control group (CG) which did not receive any counseling. This study used systematic random sampling (patient 1 (control group) $\rightarrow$ patient 2 (skip) $\rightarrow$ patient 3 (skip) $\rightarrow$ patient 4 intervention group). 


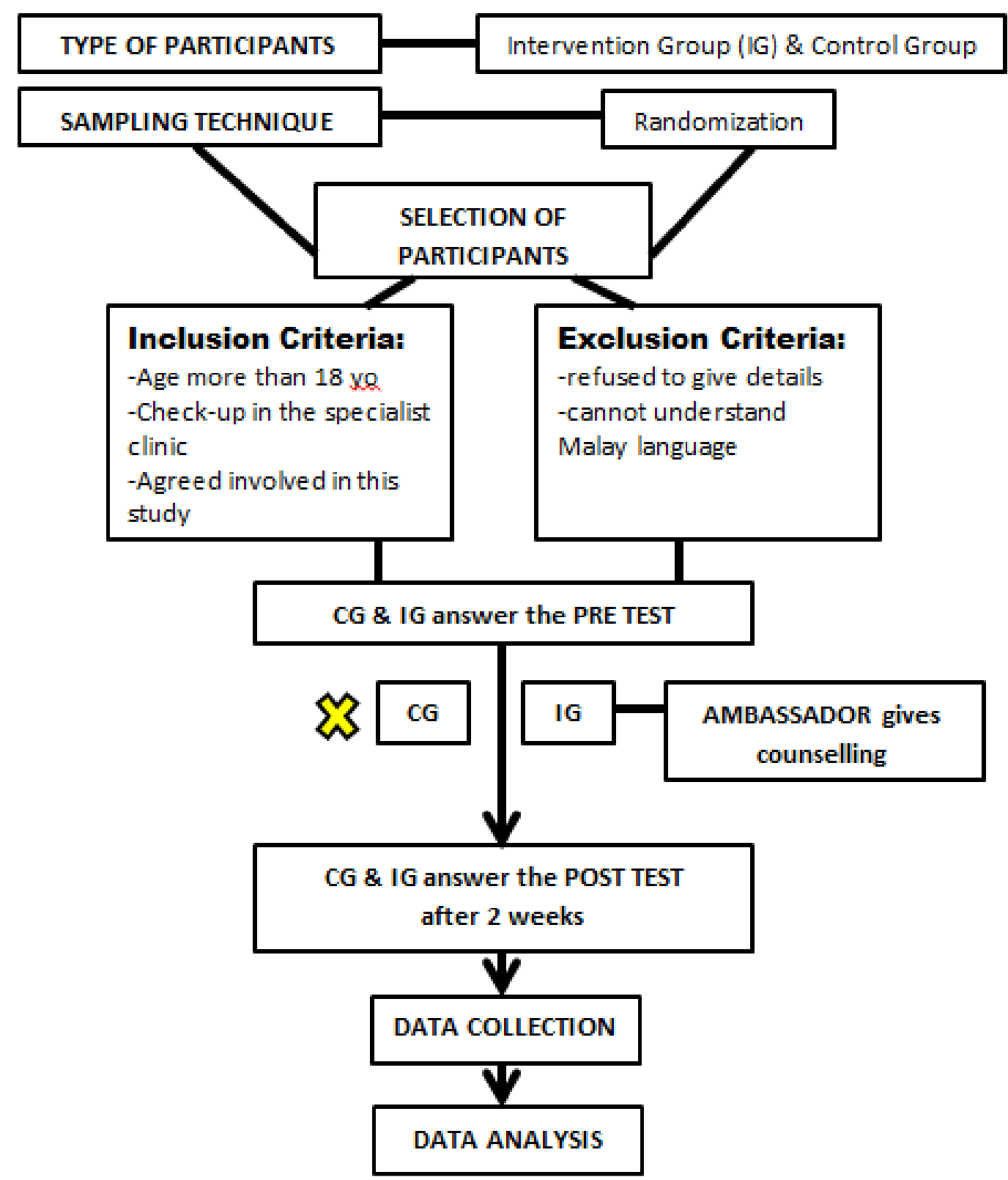

Fig.(1): Study Flowchart.

The intervention is the counseling session when the researcher gave to the IG. The researcher gave marks to the survey and then explained all of the questions to the participants. In addition, all of the researchers have a checklist of the information that they need to counsel the participants. The reason is to reduce biased in this study. Before the study begins, all of the researchers ( 4 people), have trained to use the tool and the checklist. Then, they had the assessment by the main researcher before they are certified to use the checklist.

Then, the participant had been approached and explained the procedure along with the study and they need to sign the consent letter. The post-test will be repeated after 2 weeks.
The survey was already validated [12]. The survey consists of topics that need to be answered by the participants which are; registered drugs' characteristic, cosmetics identification, advertisement and internet, adulterated food products and information references. The survey is in Malay version only.

After the participants answered the survey, the marking depends on the marks that already stated Table (2). Every question will have different marks because it depends on the weightage of the questions. The classifications of knowledge are excellent, good, acceptable, little and insufficient knowledge Table (3). The public that classified in the rate below $50 \%$ is considered to have limited knowledge 
of registered drugs. All the questions have multiple choices. If the public does not know the answer they can choose D which is, I do not know, and they will have $0 \%$ because it is considered that they did not have knowledge towards this objective.

Table (2)

Marking percentages of every question.

\begin{tabular}{||l|c|}
\hline \multicolumn{1}{|c|}{ Objective } & Portion of test (\%) \\
\hline \hline $\begin{array}{l}\text { Registered drugs' } \\
\text { characteristic }\end{array}$ & $\mathrm{N}: 4(40)$ \\
\hline Cosmetics identification & $\mathrm{N}: 2(20)$ \\
\hline $\begin{array}{l}\text { Advertisement food } \\
\text { products }\end{array}$ & $\mathrm{N}: 2(15)$ \\
\hline $\begin{array}{l}\text { Adulterated food } \\
\text { products }\end{array}$ & $\mathrm{N}: 2(15)$ \\
\hline Information references & $\mathrm{N}: 2(10)$ \\
\hline
\end{tabular}

Then, after the pre-test survey, the IG received counselling session for about 1015 minutes about the registered drugs. Finally, after 2 weeks both of the group which is IG and CG need to answer the survey again. They had contacted by the researcher by email, call or face to face meeting.

Table (3)

Classification the Marks of the level of knowledge amongst public.

\begin{tabular}{|c|c|}
\hline$\%$ & Classification of knowledge \\
\hline \hline $\mathbf{9 0 - 1 0 0}$ & Excellent \\
\hline \hline $\mathbf{7 0 - 8 9}$ & Good \\
\hline \hline $\mathbf{5 0 - 6 9}$ & Acceptable \\
\hline $\mathbf{3 0 - 4 9}$ & Little \\
\hline \hline $\mathbf{3 0}$ & Insufficient \\
\hline
\end{tabular}

Patients were contacted after 2 weeks as mentioned in the study design. If the patient cannot be contacted after 2 weeks, the sample was withdrawn without replacing with other patients. The criteria of the withdrawn sample:

- During the post-test patients disagree to continue the study (patients don't want to answer the survey)

- The researcher cannot contact the patients after 2 weeks.

- Patients contact us to answer the survey after 2 weeks.

In this research used two formula of sample size. Before began the research, the calculation of the sample size used the Raosoft calculation as below.

Population estimated 100000, based on Raosoft the sample size is 383. The participants divided into two groups which are control and intervention. The potential dropout value is considered at $4-5 \%$. The final sample size is 400 samples which are the control group and intervention group 200 each.

After we began to start to collect the data, we used the formula compare two group means sample size formula to estimate the sample size [13]. About 25 sample each group to calculate the sample by using the formula as below.

The result of the sample size is 429 . Based on these two results, the estimation for the sample size is 500. Both groups are 250 of samples.

The data was analyzed using the SPSS version 23. Descriptive data is the answers of each questions, score, level of knowledge based on the percentages and the sociodemographic data.

The pre and post differences of the score between control and intervention groups were assessed using ANCOVA.

The study was conducted in compliance with ethical principles outlined in the Declaration of Helsinki and Malaysian Good Clinical Practice Guideline. The registration number for this research is NMRR-18-149241496. Ethical approval for this study was obtained from the Medical Research and Ethics Committee (MREC), Ministry of Health Malaysia.

\section{Informed Consent/Assent Process}

Patients were informed of the study during their usual clinic visits. They were requested to contact investigators if they are interested. An appointment was made where the patient information sheet will be provided and explained to them. The consent forms were signed and dated if they expressed willingness to participate. If they need to, they were allowed to take the information sheet home to consult with their family member and another day for getting consent arranged. 


\section{Results}

A total of 657 respondents were obtained during study period (October-November 2018) with overall response rate of 93\%) Figure (2). Of these responses, $78 \%$ were obtained during face to face meeting and others via call and email. Majority of the reason for the dropout is they cannot be contacted and they contacted the researcher after the time frame which is 2 weeks after the post-test.



Fig. (2): Data Collection.

Table (4)

Demographic characteristics of the participants.

\begin{tabular}{|c|c|c|c|c|}
\hline & & $\begin{array}{c}\text { Control } \\
n(\%)\end{array}$ & $\begin{array}{c}\text { Intervention } \\
\mathbf{n}(\%)\end{array}$ & Total \\
\hline \multirow[t]{5}{*}{$\overline{A G E}$} & $18-28$ & $142(43)$ & $167(51)$ & 309 \\
\hline & $29-39$ & $82(25)$ & $82(25)$ & 164 \\
\hline & $40-50$ & $63(19)$ & $66(20)$ & 129 \\
\hline & $51-61$ & $37(11)$ & $8(3)$ & 45 \\
\hline & $>62$ & $6(2)$ & $4(1)$ & 10 \\
\hline \multirow[t]{2}{*}{ GENDER } & Male & $156(47)$ & $118(36)$ & 274 \\
\hline & Female & $174(53)$ & $209(64)$ & 383 \\
\hline \multirow[t]{4}{*}{ RACE } & Malay & $133(40)$ & $179(55)$ & 312 \\
\hline & Chinese & $156(47)$ & $112(34)$ & 268 \\
\hline & Indian & $31(9)$ & $29(9)$ & 60 \\
\hline & Others & $10(4)$ & $7(2)$ & 17 \\
\hline \multirow[t]{5}{*}{ LEVEL OF EDUCATION } & Primary & $6(2)$ & $0(0)$ & 6 \\
\hline & Secondary & $79(24)$ & $26(8)$ & 105 \\
\hline & Diploma & $46(14)$ & $43(13)$ & 89 \\
\hline & Degree & $196(59)$ & $258(79)$ & 454 \\
\hline & Others & $3(1)$ & $0(0)$ & 3 \\
\hline \multirow[t]{6}{*}{ OCCUPATION } & Government & $115(35)$ & $137(42)$ & 252 \\
\hline & Private & $136(41)$ & $88(27)$ & 224 \\
\hline & Self & $26(8)$ & $32(10)$ & 58 \\
\hline & Pensionner & $9(3)$ & $18(6)$ & 27 \\
\hline & Unemployed & $7(2)$ & $12(3)$ & 19 \\
\hline & Student & 37 (11) & 40 (12) & 77 \\
\hline
\end{tabular}


Based on Table (5), the majority of the participants are age between 18 -28 years old (47\%), female (58.3), Malay (47.4\%), Degree holder $(69.1 \%)$ and in the government sector $(38.3 \%)$.

Table (5)

The majority of participants' answers.

\begin{tabular}{|c|c|c|}
\hline$\overline{\text { Questions (Q) }}$ & Answer & $\mathbf{N}(\%)$ \\
\hline $\begin{array}{l}\text { Q1 What is the registered drug } \\
\text { in Malaysia? }\end{array}$ & $\begin{array}{c}\text { Medicines that have been } \\
\text { approved by the Drug Control } \\
\text { Authority (DCA) and have } \\
\text { tested efficacy, quality and } \\
\text { safety. }\end{array}$ & $288(43.8)$ \\
\hline $\begin{array}{l}\text { Q2 Below is a fact about the } \\
\text { product registration category. } \\
\text { Please choose the TRUE } \\
\text { statement? }\end{array}$ & $\begin{array}{c}\text { Traditional medicine is marked } \\
\text { "T" at the end of the registration } \\
\text { number }\end{array}$ & $335(50.9)$ \\
\hline Q3 Registered drug has & I do not know & $260(39.5)$ \\
\hline $\begin{array}{c}\text { Q4 The tool used to detect the } \\
\text { authentic of the Meditag } \\
\text { holographic sticker is }\end{array}$ & Infrared Device. & $293(44.6)$ \\
\hline $\begin{array}{l}\text { Q5 Please select the TRUE } \\
\text { statement about cosmetic } \\
\text { products below. }\end{array}$ & $\begin{array}{l}\text { Having a notification number for } \\
\text { example is NOT98727124K. }\end{array}$ & $287(43.7)$ \\
\hline $\begin{array}{l}\text { Q6 To ensure your cosmetic } \\
\text { products do not have any } \\
\text { hazardous materials such as }\end{array}$ & $\begin{array}{l}\text { Hidrokuinon, Merkuri, } \\
\text { Tretinoin. }\end{array}$ & $443(67.4)$ \\
\hline $\begin{array}{c}\text { Q7 Please select TRUE } \\
\text { statement about drug advertising } \\
\text { or purchase of medicines via the } \\
\text { internet below. }\end{array}$ & $\begin{array}{c}\text { All products with medical claims } \\
\text { have a KKLIU registration } \\
\text { number in the ads. }\end{array}$ & $430(65.4)$ \\
\hline $\begin{array}{c}\text { Q8 Please select a reliable ad } \\
\text { statement below }\end{array}$ & $\begin{array}{l}\text { This product can increase our } \\
\text { body's resistance. }\end{array}$ & $447(68.0)$ \\
\hline $\begin{array}{l}\text { Q9 From which sources do you } \\
\text { get information on health care, } \\
\text { disease and product health? }\end{array}$ & $\begin{array}{l}\text { Doctors and pharmacists at } \\
\text { nearby hospitals, clinics or } \\
\text { pharmacies. }\end{array}$ & $534(81.3)$ \\
\hline $\begin{array}{l}\text { Q10 Please select the TRUE } \\
\text { statement below }\end{array}$ & $\begin{array}{l}\text { If the general public is exposed } \\
\text { to dubious drug sales, they need } \\
\text { to complain to the authorities } \\
\text { immediately. }\end{array}$ & $417(63.5)$ \\
\hline $\begin{array}{l}\text { Q11 Please select the TRUE } \\
\text { statement below }\end{array}$ & $\begin{array}{l}\text { Sildenafil and steroids cannot be } \\
\text { mixed into health products as it } \\
\text { can damage your health. }\end{array}$ & $377(57.4)$ \\
\hline $\begin{array}{l}\text { Q12 Please select a FALSE pre- } \\
\text { mixed pair for violation of the } \\
\text { law. }\end{array}$ & Tea and Sildenafil drinks & $367(55.6)$ \\
\hline
\end{tabular}

Based on Table 6, question number 3, majority of the participants did not know the answer (39.5\%) and question number 4, majority of the participants answered wrongly $(44.6 \%)$. However, majority of the participants answered correctly for other questions. 
Table (6)

The score of the Pre-test.

\begin{tabular}{||c||c|}
\hline Level of knowledge (\%) & N (\%) \\
\hline \hline Excellent (90-100) & $23(3.5)$ \\
\hline Good (70-89) & $143(21.8)$ \\
\hline Acceptable (50-69) & $268(40.8)$ \\
\hline Little (30-49) & $126(19.2)$ \\
\hline Insufficient (<30) & $97(14.8)$ \\
\hline
\end{tabular}

Based on Table (6), the majority of participants are in the category of the acceptable level of knowledge towards registered drugs $(40.8 \%)$ and only $3.5 \%$ of the participants are in the category of excellent. However, about $66.1 \%$ of the participants scored above $50 \%$ and it can be considered that the majority of the participants have knowledge about registered drugs.

The pre and post differences of the score between control and intervention groups were assessed using ANCOVA. The result after analysis using ANCOVA showed that it is statistically significant approved $(\mathrm{p}<0.001)$ between the group for the post test.

\section{Discussion}

According to the descriptive data, the majority of the patients that follow up in the specialist clinic are in the government sector. Moreover, most of the patients that easily been approached during the selection of the sample are female, educated (degree holder) and age between $18-28$ years old. Others sample do not have the inclusion and exclusion criteria and had to be excluded from this study. The reason to choose the specialist clinic as the main setting of this research is to have a population that has a regular check up with any clinic.

Meanwhile, the majority of the respondent answered the test correctly. However, there have two questions in which the majority of the respondent answered wrongly and answered they did not know the answer. Both questions are under category characteristic of registered drugs which is one of the important questions that public need to know [12]. Based on this result, in the future can focus more to assess public about the characteristics of the registered drugs and have the hands-on session to make it more interactive.

For this study, the result is more than $50 \%$ of respondents have marks above 50\% compared to other research that conducted awareness survey [5] [12]. But again, the answer of every question needs to check to ensure that the public really understands about the registered drugs and can identify what topic that they are still lacking and focus to give education towards that topic.

The result after analysis using ANCOVA showed that it is statistically significant approved $(\mathrm{p}<0.00)$ between the group for the post test. The previous study also get the same result but she has the descriptive data. In this research used ANCOVA which showed that the tool gave a significantly positive impact to the public.

\section{Implications/Conclusion}

The implementation of the validated survey during the awareness programmes reflects potential benefit to the public who attends the campaign and can improve the effectiveness of the programmes in the future.

Furthermore, the usefulness of this finding not only limited to pharmacists and public but also for other health care professionals. The authorised body should take action such as making it compulsory for health care provider learning to use the tool and act as an ambassador for the public in giving awareness towards the registered drugs. Therefore, the burden not only for the pharmacists to give the knowledge to the public but also can be shared with other health care providers. The cooperation amongst health care provider regarding these issues might help to improve the understanding of the public towards registered drugs.

\section{Acknowledgement}

We would like to thank the DirectorGeneral of Health Malaysia for his permission to publish this article.

\section{Conflicts of Interest}

None declared.

\section{Funding}

The study was undertaken within the Ministry of Health activities. This study is not funded by any organization. 


\section{References}

[1] Charlotte, W. LLB. \& M. Phil. (2011). Drugs, the Internet and Change. Journal of Psychoactive Drugs, 43(1), 55-63.

[2] FDA. (2014, April 3). Development \& Approval Process (Drugs). Food and Drug Administration Official Homepage. Florida. Retrieved from http://www.fda.gov/Drugs/ DevelopmentApproval Process/

[3] Salmah, B. (2012). Malaysia: Pharmacy Transformation Planning - Reform for Universal Access to Medicines. Asia Pacific Conference on National Medicines Policies 26-29 ${ }^{\text {th }}$ May 2012. Sydney, Australia.

[4] NPCB. (2014, April 3). FAQ: Product Registration. National Pharmaceutical Control Bureau Official Homepage. Kuala Lumpur. Retrieved from http://portal.bpfk.gov.my/index.cfm?\&men uid $=96$

[5] Rasyimah O., Nor Syuhada M.K, Mohd Azwadi K., Wan Shamsun Bahari W.M., Shaira Shuwari S., Hasni Muniati H. (2013). Menilai Kefahaman Tentang Produk Berdaftar Di Kalangan Kakitangan Kesihatan Negeri Kelantan, Cawangan Penguatkuasa Farmasi Negeri Kelantan, KIKF, Bahagian Perkhidmatan Farmasi.

[6] Azmi, M., Akmal, A., with, C.G.N., Fauziah, S., St, L., Ak, N., Lj, S. (N.D.). (2012) A National Survey on the Use of Medicines (NSUM), 1-120. Bahagian Perkhidmatan Farmasi, Malaysia.

[7] BPF. (2012). Buku Statistik Penguatkuasaan Farmasi Tahun 2012. Bahagian Perkhidmatan Farmasi Kementerian Kesihatan Malaysia. Selangor.

[8] Philip, S. \& Helmy, H. M. (2013). Fake Medicines in Asia. Emerging Markets Health Network (EMHN), 1, February 2013. Malaysia.

[9] Abd. Rahim, N. H., Ahmad Saeead, N., Abdullah, M. T. \& Abd Aziz, N. (2015). Study of Adverse Drug Reactions Related to Unregistered Traditional Medicines in Malaysia. International Journal of Pharmacy and Pharmaceutical Sciences, $8(2), \quad \mathrm{p}-41$. Conference on the Pharmaceutical, Nutraceutical and Cosmetic Sciences (IPNaCS 2015), Melaka, Malaysia.
[10] Nasra, A.S. (2016). Effect of Counterfeit Drugs on Distribution of Pharmaceutical Products in Mombasa County, Kenya. Thesis. Master of Business Administration School of Business, University of Nairobi.

[11] Olike, C. (2008). The fight against fake drugs by NAFDAC in Nigeria. 44th International Course in Health Development (ICHD) September 24, 2007 - September 12, 2008. KIT (Royal Tropical Institute) Development Policy \& Practice/ Vrije Universiteit Amsterdam

[12] Nur Wahida, Z., Noorizan, A. A., Yahaya, H., Mohamed, A. H. \& Nur Liyana, Z. B. (2015). Development of Validated Questionnaire to Access Public Knowledge on Registered Drugs. Procedia - Social and Behavioral Sciences. 172, P:749753.

[13] S. Lemeshow, D.W. Hosmer, J. Klar, S.K. Lwanga, W.H. Organization, others, Adequacy of sample size in health studies, (1990).

[14] Darshana, Bennadi. 2013. Selfmedication: A current challenge. J Basic Clin Pharm; 5(1): 19-23.

[15] Bonin, C.D.B. Santos, R.Z. Dos, Gisi, G.L.D.M., Vieira, A.M., Amboni, R., \& Benetti, M. (2014). Construction and Validation of a Questionnaire about Heart Failure Patients ${ }^{\text {ee }}$ Knowledge of Their Disease. Arquivos Brasileiros de Cardiologia. 